\title{
Toward a Social Justice Model for an EdD Program in Higher Education
}

\author{
Phillis George \\ Department of Leadership and Counselor Education \\ plgeorge@olemiss.edu
}

\begin{abstract}
Evaluative in nature, this article includes an initial examination of a doctoral program uniquely designed to prepare higher education administrators and practitioners to be socially just and equity-minded leaders. The program emphasizes the integration of equity, social justice, and ethics into professional practice. As such, this article utilizes a social justice, leadership framework. Originally designed in 2006 by Colleen Capper, George Theoharis, and James Sebastian to prepare secondary administrators for social justice leadership, the framework assists with the enclosed evaluation of a program that prepares postsecondary administrators for social justice leadership. The article delineates the effectiveness of the program's implementation and the extent to which the program's goals, curriculum, and pedagogy align with components of the framework. The program has been chosen because of its commitment to addressing socio-economic and educational attainment disparities in higher education through the focused teaching and professional development of academic and student affairs personnel.

KEYWORDS

social justice, higher education, EdD
\end{abstract}

Higher education is currently undergoing a change, as social and restorative justice issues are working their way to the academic core. Within this climate, institutions are responding to a clarion call to address socio-economic and educational attainment disparities by attending to systemic issues of limited access and inequitable practices that impede student success (Bowen \& McPherson, 2016). The end goal is to eliminate persistent attainment and achievement gaps among all student demographics. As they begin this work, colleges and universities of various settings, types, and sizes are learning they lack the required infrastructure (e.g., curricula, pedagogy, and assessments) and resources (both human and monetary) to meaningfully take on equity challenges regarding college access, persistence, and completion (Bok, 2006).

Arguably, this incomplete infrastructure has existed for some time, as institutions have made limited systemic, effort to substantively address the aforementioned equity issues (Tinto, 1993, 2012). This persistent inaction and inattentiveness across the higher education landscape can be, and has been, viewed by many as ethically egregious and neglectful (Bok, 2006). Disconcertingly, in the current performance-based, funding environment, primacy is given to increased output relating to college completion; yet, the equity disparities concerning access and student success have become even more pronounced and societally problematic (Hillman, Tandberg, \& Gross, 2014; Rabovsky, 2012; Tandberg \& Hillman, 2014; Tandberg, Hillman, \& Barakat, 2015; Volkwein \& Tandberg, 2008). Consequently, institutions are being held more accountable for taking an active role in mediating inequity on their campuses (Berg, 2010; Dickert-Conlin \& Rubenstein, 2007; Taylor, Beck, Lahey, \& Froyd, 2017). In particular, they are asked to make visible the critical and operational linkages that exist between their espoused and enacted goals of equity and excellence in access and student success. As an embodied collective, higher education institutions are increasingly encouraged to not only honor their equity commitment (i.e., to college access) but also improve access to high quality learning, while adhering to an ever-growing and unrelenting push toward timely degree completion (Complete College America, 2013). Although not mutually exclusive, in the current higher education landscape, the latter (i.e., degree completion) seemingly serves as the ultimate accountability measure and indicator of student success (Braxton, Doyle, Hartley, Hirschy, Jones, \& McLendon, 2014; Seidman, 2012; Tinto, 2012).

In elevating the role and importance of degree completion, an inherent tension is exposed between institutional accountability and improvement concerning equity and excellence in college access and student success. According to Ewell (2009), "accountability requires the entity held accountable to demonstrate, with evidence, conformity with an established standard of process or outcome" ( $p$. 7). In relating this definition to today's higher education landscape, timely degree completion becomes an "established standard of process or outcome" for which higher education "entities" or colleges and universities are held accountable (Ewell, 2009, p. 7). Ewell (2009) further states, "the associated [accountability] incentive for that entity is to look as good as possible, regardless of the underlying performance" (p. 7). In contrast, Ewell (2009) describes improvement as "entailing an opposite set of incentives" whereby "deficiencies in performance must be faithfully detected and reported so they can be acted upon" (p. 7). In relating these incentive-based descriptions of
New articles in this journal are licensed under a Creative Commons Attribution 4.0 United States License.

This journal is published by the University Library System of the University of Pittsburgh as part of its D-Scribe Digital Publishing Program and is cosponsored by the University of Pittsburgh Press.

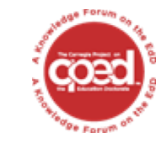

This journal is supported by the Carnegie Project on the Education Doctorate: A Knowledge Forum on the EdD (CPED) cpedinitiative.org

impactinged.pitt.edu Vol.2 (2017)
ISSN 2472-5889 (online) DOI 10.5195/ie.2017.29 
accountability and improvement to $21^{\text {st }}$ century higher education, equity challenges, there is great irony because the accountability incentive (i.e., to improve completion rates) rivals and, in many ways, eclipses institutional incentives to improve and address underlying deficiencies in more expansive equity performance measures concerning access and student success.

Given this dueling reality, how do institutions reconcile increased calls of accountability regarding college completion with improvement efforts, so as not to undermine their ability to develop more complete, effective, and equitable infrastructures that support increased college access and student success for all? Improvement relates to "the underlying performance" of an institution using a variety of indicators, not just degree completion (e.g., student learning, student engagement, student motivation, academic and self-efficacy, etc.) (Ewell, 2009, p. 7). It is assumed that improving underlying performance measures serves as a useful means to address systemic issues of inequity in higher education. By focusing on these measures (which are all encompassing), the hope is that colleges and universities will be able to comprehensively solve their equity challenges and better respond to societal needs and demands for increased access and student success, while holding themselves to an even greater standard of accountability (i.e., increases in college completion rates for all student demographics).

So, how will institutions accomplish these equity goals? Also, who among institutional officials will be charged with doing the heavy lifting to realize the aforementioned improvement and accountability outcomes? The short answer entails an institutional reliance on intermediate and senior-level administrators or practitioners who are charged with overseeing curricular and co-curricular programming designed to promote college student learning, development, and (ultimately) success. A more nuanced answer concerns the provision of focused teaching and targeted, professional development for academic and student affairs personnel, so that they might possess the requisite knowledge and skills needed to develop and sustain the institutional foci of accountability and improvement in access and student success.

The enclosed article promotes the idea that the referenced knowledge-base and skill set should include (at the very least) an understanding of social justice leadership and equity mindedness (Bensimon, 2007; Dowd \& Bensimon, 2015), with both serving as a unique lens through which administrators can view and perfect their work in upholding institutional accountability and improvement efforts. Equity-mindedness is defined as "the perspective or mode of thinking exhibited by practitioners who call attention to patterns of inequity in [college] student outcomes" (Center for Urban Education, University of Southern California, n.d., para. 1). This mindset prompts practitioners to question whether their personal and/or institutional practices are inequitable and exclusionary (Center for Urban Education, University of Southern California, n.d.). Building on that definition, social justice leadership is defined here as the intentional manner in which higher education administrators and practitioners "make issues of race, class, gender, disability, sexual orientation, and other historically and currently marginalizing conditions in the United States central to their advocacy, leadership practice, and vision" (Theoharis, 2007, p. 223). Evaluative in nature, this article includes an initial examination of a doctoral program uniquely designed to prepare higher education administrators and practitioners to be socially just and equity-minded leaders who are focused on "addressing and eliminating marginalization" in higher education (Theoharis, 2007, p. 223).
More specifically, the program emphasizes the integration of equity, social justice, and ethics into professional practice. From a programmatic and evaluative perspective, equity focuses on eliminating disparities in higher educational outcomes (i.e., student success and college completion), regardless of one's identity, orientation, or background (Center for Urban Education, University of Southern California, n.d.). Equity is not to be confused with equality, which "refers to the social ideal that society regards and treats its citizens as equals and that benefits...should be distributed equally" (Nelson, Creagh, \& Clarke, 2012, p. 4). Equity, within the current analysis, moves beyond the provision of equal opportunities for college access and focuses more on student outcomes-namely college retention and completion-for historically underrepresented and marginalized collegians (Center for Urban Education, University of Southern California, n.d.).

Within this analytic and evaluative context, social justice refers to intentional actions, policies, and decisions (e.g., of administrators, practitioners, institutions, or policy makers) that are designed to eradicate social disparities and promote equity and inclusivity. The degree to which those actions, policies, and decisions adhere to informal and formal, socially agreed upon principles that respect the value, identity, and worth of all individuals ultimately determines the ethical nature of any socially just practice or set of practices. This article relies upon these working definitions of equity, social justice, and ethics and pairs them with a social justice leadership framework to delineate the effectiveness of the program's implementation and the extent to which the program's goals, curriculum, and pedagogy align with components of the framework. To be clear, the program has been chosen because it attempts to address socio-economic and educational attainment disparities in higher education by working with the very professionals tasked with leading the charge.

\section{DEFINING THE ROLES OF EQUITY, SOCIAL JUSTICE, AND ETHICS IN LEADERSHIP}

\section{Equity}

From a higher educational professional standpoint, the question of how to equitably, justly, and ethically carry out this complex task with constrained budgets as well as inadequate infrastructural and human resources is daunting. There is arguably a great need for more professionals who are proficient and mindful in their efforts to seamlessly integrate social justice and ethics into their practice, while promoting equity in institutional accountability and improvement outcomes. For some time now, researchers, practitioners, and policy analysts have sought to address this need on the secondary end of the educational continuum (Brown, 2006; Dantley \& Tillman, 2006; McKenzie et al., 2008; Theoharis, 2007); however, the need for more professionals with the ability "to transform [postsecondary] schools into equitable contexts focused on social justice" has persisted (Guerra, Nelson, Jacobs, \& Yamamura, 2013, p. 128). Without such individuals, efforts to promote greater college access, success, and completion could potentially be undermined, thus reinforcing institutional deficiencies and ineffectiveness in achieving educational parity. Ideally, there would already be an ample supply—indeed, an overflow—of higher education administrators and practitioners in possession of the professional mindedness and commitment to equity, social justice, and ethics needed to affect positive change across institutional types. Since this is not yet the case, there is great justification for the 
development of doctoral programs uniquely designed to populate the profession with more individuals (i.e., administrators and practitioners) who uphold and value equity as the intentional provision of multifaceted and robust opportunities for equal access and success for all student demographics in higher education, most especially historically underrepresented and socio-economically disadvantaged students (Bensimon, 2007; Dowd \& Bensimon, 2015).

\section{Social Justice}

The hope is that these individuals, as a result of their preparation, would understand and make administrative meaning of the fact that for far too long, underrepresented and marginalized students have experienced limited returns on their educational investments due to a complex labyrinth of systems and processes uniquely designed to disadvantage them in their higher educational pursuits (Bowen, Chingos, \& McPherson, 2009). Further, these individuals would be willing to act on their in-depth understanding of the persistent and long-lasting consequences of educational inequity. Their enhanced, professional awareness would presumably lead to direct engagement in advocacy work designed to develop and sustain more equitable flows of higher educational access, opportunity, and attainment. By engaging in this focused work, individuals would (i.e., by the nature and scope of their professional actions) promote socially just principles, thus forming-be it intentionally or unintentionally - the basis and strong foundation for social justice leadership.

\section{Ethics}

Within the confines of this article, social justice leadership is operationalized as the fair and proper administration of higher education systems, processes, and policies that recognize and value all persons as equals without discrimination or prejudicial treatment. In adhering to this operationalized conceptualization, individuals would affirm and adopt a core philosophy of fairness or code of ethics that would ultimately shape and influence their administrative decisions and actions. The greatest beneficiary of this professional adherence would be college and university students, as they would then have an inexhaustible, designated, and trained group of social justice leaders continuously advocating on their behalf to ensure equity and excellence in college access, success, and completion. This is the vision with which the current article was first conceived. The goal was and is to identify and evaluate a doctoral program that prepares higher education administrators and practitioners for social justice leadership.

\section{AN EMPLOYED SOCIAL JUSTICE AND LITERARY FRAMEWORK}

Initially designed for secondary education doctoral leadership programs, the critical framework utilized within this article was created in 2006 by Colleen Capper, George Theoharis, and James Sebastian and first previewed in an original article-aptly titled, "Toward a Framework for Preparing Leaders for Social Justice." Arguably a visionary framework in the past and even more so in the present, this conceptual tool was designed to intentionally prepare secondary education administrators for effective, social justice leadership. Specifically, it provided secondary administration programs with a working conceptualization of the preparatory process by focusing on seven domains-which the authors argued that if properly addressed will maximize the learning goals and help fully realize the potential of leadership for social justice among education doctoral students (Capper, Theoharis, \& Sebastian, 2006, p. 221). As shown in Appendix A, the horizontal dimension of the framework includes four very active domains: (1) emotional safety for risk taking, (2) critical consciousness, (3) focused knowledge, and (4) a practical skill set regarding social justice leadership. In order to achieve and sustain the aforementioned, the vertical dimension delineates three required components of an administrative preparatory program (i.e., for social justice leadership): (1) relevant curriculum, (2) critical pedagogy, and (3) ongoing, programmatic assessment.

The framework is employed within the current analysis to suit the preparatory and professional development needs of Higher Education Administration doctoral students. Although there are seven referenced domains, the very first domain (i.e., emotional safety for risk taking) is active across all domains. Capper et al. (2006) acknowledge that students cannot fully invest themselves in the critical work required to become social justice leaders if the learning environment is not emotionally and intellectually safe ( $p$. 212). As such, this domain is presumed to be an omnipresent constant within the program, and therefore appears in the upper left corner of the chart (see Appendix A).

It is important to note that much of the research in Higher Education Administration regarding social justice leadership is bifurcated. One core research focus includes civic engagement, community outreach, and service-learning as a social justice and improvement platform. This body of research is very studentcentered and community-oriented and is generally comprised of three themes: (a) reciprocity embedded within strategic, universitycommunity collaborations (Carlton, Whiting, Bradford, Hyjer Dyk, \& Vail, 2009; Thompson, 2003); (b) civic engagement and its influence on college access and success (Cress, Burack, Giles, Elkins, \& Stevens, 2010; Simonet, 2008); and (c) the influence of servicelearning on student engagement (Caruso, Bowen, \& Adams-Dunford, 2006). While important regarding its' contributions to the discipline and field of practice, this body of research does not contribute as meaningfully to the current analysis-which focuses on the preparation of higher education professionals and administrators for social justice leadership.

There is, however, a second body of research that is more applicable. Studies included in this latter research strand focus indirectly on transforming higher education leadership preparation by concentrating holistically on higher education leadership and embedded opportunities for social justice practice. These studies focus almost entirely on promoting (a) diversity leadership (Asumah \& Nagel, 2014; Asumah, Nagel, \& Rosengarten, 2016; Guerra \& Pazey, 2016; Kotter, 1990; Mor Barak, 2014; Northouse, 2013; Olsen \& Martins, 2012; Rost, 1991) and (b) inclusive excellence (Williams, Berger, \& McClendon, 2005). To be clear, there are a host of studies that focus on social justice issues in higher education, but this particular body of research speaks to a unique set of knowledge, skills, employed strategies, principles, and beliefs that inform the work of the selected doctoral program.

\section{Diversity Leadership}

There is a critical distinction between diversity management and diversity leadership (Asumah, Nagel, \& Rosengarten, 2016; Kotter, 1990; Rost, 1991). Diversity management has an overriding focus on 
maintaining order regarding an organization's systems and processes (Northouse, 2013). Maximizing organizational efficiencies becomes a core focus. Diversity management in this context is typically one-way, unilateral, and highly simplex (Rost, 1991). To the extent that social justice and equity-based decisions contribute to the causes of organizational efficiency and order, diversity management can potentially inform and shape social justice practices in higher education. Whether referencing (a) voluntary but deliberate, organizational policies and practices designed to promote diversity and inclusion (Mor Barak, 2014) or (b) the strategic ordering and placement of diverse human resources to maximize organizational efficiency (Olsen \& Martins, 2012), diversity managementespecially from a higher education administrative standpoint-is usually considered to be quite limiting because of a tendency to situate diversity, equity, and inclusion efforts within a corporate and capital-based framework (Asumah \& Nagel, 2014; Asumah, Nagel, \& Rosengarten, 2016).

This is problematic because such a framework does not easily lend itself to critical social theory which "views people as subjects, not objects, who are constantly reflecting and acting on the transformation of their world so it can become a more equitable place for all to live" (Brown, 2004, p. 85). Within this article, critical social theory is applied to a higher education, leadership context. Administrators and practitioners reflect and act on transforming colleges and universities into more equitable learning environments for all student demographics. Therefore, critical social theory (i.e., through a higher education, administrative lens) is considered an active and ever-contributing component of diversity leadership, which fundamentally differs from diversity management.

Although seemingly complex, diversity leadership is really quite simple. It "is about redefining and rethinking problems in creative ways and the transformational approaches to overcoming difficult dialogues and raising human consciousness to implement [social justice] goals and policies" (Asumah, Nagel, \& Rosengarten, 2016, p. 143). In order to implement and sustain diversity leadership, a paradigm shift is required, so too is institutional adherence and expanded thinking about diversity, equity, and inclusion. While still concerned with organizational efficiency and achieving structured goals, diversity leadership focuses intently on progressive growth and innovation (Northouse, 2013) from a multi-level and multistakeholder perspective (Rost, 1991). This distinction is important because unidirectional decision-making from a corporate maximization stance is antithetical to the collective thinking and creative problem-solving needed to produce changes and progressive movement within higher education institutions seeking to eradicate educational disparities in college access, success, and completion.

Diversity leadership in higher education entails an intensely transformational approach to social change efforts relating to educational and socio-economic attainment (Asumah, Nagel, \& Rosengarten, 2016). Senior officials who take up the mantle of diversity leadership understand and appreciate that their own efforts are critical for role-modeling and helping lead the institutional charge (Guerra \& Pazey, 2016). In truth, there is no real substitute for diversity leadership and its primary role in helping to construct a core and effective philosophy of social justice leadership-which is why diversity leadership helps to inform the current programmatic evaluation.

\section{Inclusive Excellence}

In addition to diversity leadership, inclusive excellence plays an important role in helping shape an individual's initial commitment to and operational understanding of social justice leadership. In fact, for the purposes of this evaluative article, these two principles are highly complementary and work in concert. To briefly review, diversity leadership is about creative thinking and transformational problem solving, especially about issues of equity and excellence in higher education. Inclusive excellence helps ensure that the aforementioned transformation is long lasting and fully inclusive because of the commitment to enhancing student success and academic achievement, especially for marginalized and historically underrepresented student populations (e.g., ethnic minority, first generation, and socio-economically disadvantaged collegians). As a core principle of social justice leadership, inclusive excellence is comprised of four primary components: (1) a focus on student intellectual and social development; (2) a purposeful development and utilization of organizational resources to enhance student learning; (3) attention to the cultural differences learners bring to the educational experience and that enhance the enterprise; and (4) a welcoming community that engages all of its diversity in the service of student and organizational learning (Williams, Berger, \& McClendon, 2005, p. vi)

There is no mistaking the significance of these active components in ensuring equity, social justice, and ethics in higher education policy and administrative decision-making. To underscore their importance and further their legitimacy, the Association of American Colleges and Universities (AACU) has adopted inclusive excellence (and each of its components) as a guiding principle in the promotion of improved college access, success, and completion. AACU acknowledges that inclusive excellence "is designed to help colleges and universities integrate diversity, equity, and educational quality efforts into their missions and institutional operations" (n.d., para. 1). In fact, higher education administrators seeking to achieve inclusive excellence on their campuses must focus on these components or (restated) "on the 'big picture'-an academy that systematically leverages diversity for student learning and institutional excellence-and the myriad individual pieces that contribute to that picture" (Williams, Berger, \& McClendon, 2005, p. v). With so many moving and critical pieces, focused, doctoral preparation for administering higher education programs (both curricular and co-curricular) while upholding the principles of diversity leadership and inclusive excellence is expressly needed-which is why the current evaluation of the selected doctoral program is timely and important.

The embedded analysis of the Higher Education Administration doctoral program is predicated on the notion that "the sustainability of inclusive excellence in [higher] education is dependent upon the quality of diversity leadership over and above the corporate style diversity management, which is a linear approach to problem solving" (Asumah, Nagel, \& Rosengarten, 2016, p. 141). Ultimately, what is being promoted within the selected doctoral program are intentionally redefined, restructured, and non-linear approaches to solving persistent and complex problems of higher education practice that have-for far too long —created and/or perpetuated educational inequities in college access, success, and completion.

This article attempts to expand on the (a) referenced principles of diversity leadership and inclusive excellence and (b) related bodies of research that focus on transforming higher educational 
leadership preparation by employing the social justice framework illustrated in Appendix A. Again, although intended for secondary education leaders, the selected framework affords a unique and much needed opportunity to conceptualize and assess the professional development and preparation of leaders for social justice within a higher education setting. The remaining portions of this article will focus intently on achieving this goal by evaluating the aforementioned program.

\section{METHODS}

As mentioned, the enclosed discussion of social justice leadership draws on a social justice framework adopted from Capper, Theoharis, and Sebastien (2006) and is contextualized within an evaluative assessment of an emergent doctoral program with an emphasis in Higher Education Administration. As an adherent to the espoused and enacted principles of the Carnegie Project on the Education Doctorate (CPED), ${ }^{1}$ the selected program is highly attentive to issues of equity, social justice, and ethics and seeks to admit college and university professionals-with foci in both academic and student affairs-who desire a practitioner focus in their doctoral studies and who are receptive to a critical social justice approach in their doctoral preparation as well as in their professional practice. Given the unique nature of the program and its core mission of developing and cultivating the critical thinking and decision-making skills of higher education professionals through a social justice lens, this article utilizes a social justice framework to assess the overall effectiveness and manner in which the emergent program prepares higher education leaders with a mindfulness toward equity, social justice, and ethics as well as a demonstrated knowledge of how to continually integrate the three into professional practice.

In utilizing the framework, emphasis is placed on the program's implementation. As such, the qualitative application employed within this study is essentially an implementation evaluation. Patton (2015) characterizes implementation evaluation as an evaluative process that "documents the extent to which an intervention [program] has been implemented as planned ..." (p. 197). He further states that "studying program implementation involves gathering detailed, descriptive information about how an intervention or program operated, or is operating ..." (Patton, 2015, p. 197). The employed methodology should "be open-ended, discovery oriented, and capable of describing developmental processes and program changes" (Patton, 2015, p. 197). These methodological guides are strictly adhered to within the current programmatic evaluation-which entails "case data rich with the details of program content and

\footnotetext{
${ }^{1}$ A consortium of over 80 schools of education committed to improving educational preparatory programs (secondary and postsecondary), CPED (http://www.cpedinitiative.org/) adheres to six working principles to prepare leaders for the application of appropriate practices, generation of new and complex funds of knowledge, and effective stewardship of the profession. The first, working principle includes questions of equity, ethics, and social justice to solve complex and persistent problems of educational practice. It is that principle which is substantively addressed within the current analysis.
}

context" as it relates to the development and preparation of social justice leaders in higher education (Patton, 2015, p. 198).

It is worth noting that because the selected doctoral program is only in its second year of implementation, comprehensive, assessment data is not yet available. Therefore, the assessment domain of the employed social justice framework has been excluded from the current implementation evaluation. Even so, it is important to note that the assessment of program outcomes is not the focus of this evaluation. Patton (2015) is a strong advocate of implementation evaluation prior to evaluating programmatic and/or intervention outcomes. His logic is based on the assumption that "unless a program is operating as designed, there is little reason to expect it to produce the desired outcomes" (Patton, 2015, p. 197). The selected program was and is designed to prepare social justice leaders in higher education. This is the desired student outcome, and the program should ultimately be designed and implemented to focus intently on social justice leadership. The current analysis helps determine the effectiveness of the program's implementation and seamless integration of the adopted, social justice leadership framework into its core curricula and pedagogies. The implementation process is important because "when outcomes are evaluated without knowledge of implementation, the results seldom provide a direction for action because the decision maker lacks information about what produced the observed outcomes (or lack of outcomes)" (Patton, 2015, p. 197). The enclosed implementation evaluation has been conducted to help avoid such an oversight.

\section{DEVELOPING A HIGHER EDUCATION DOCTORAL PROGRAM FOR SOCIAL JUSTICE LEADERSHIP}

Nestled within a larger department of Leadership and Counselor Education that includes two additional, academic programs (Educational Leadership and Counselor Education), the selected, academic program ${ }^{2}$ boasts of four, graduate degree offerings: (1) online Master of Arts, (2) residential Master of Arts, (3) residential Doctor of Philosophy, and (4) hybrid Doctor of Education. The academic program is comprised of seven-soon to be eightfull-time faculty and a cadre of adjunct instructors with specialized experiences and expertise in higher education administration. The Doctor of Education (EdD)—which is the focus of the current, evaluative analysis - is the most recently developed of all of the graduate degree programs; yet, it is among the fastest growing and largest. Now in its second year of implementation, the EdD program is comprised of two cohorts. The first cohort includes 47 higher education professionals, and the second includes 25 mid- and senior-level practitioners. All applicants must hold a master's degree in Higher Education Administration, Student Personnel Services, or a related field in addition to possessing a minimum of two years of administrative experience in higher education. Although seemingly

\footnotetext{
${ }^{2}$ The selected, academic program was recently approved by its state governing board to form a single and separate department, distinct from its current departmental home. The departmental transition is currently underway but will not alter the current degree offerings nor programmatic structure.
} 
restrictive, the aforementioned requirements for admission help ensure that all applicants (and matriculants) are higher education practitioners, as the purpose of the program is to enhance the critical thinking and decision-making skills of higher education administrators and practitioners using a critical social justice approach.

\section{Promoting Critical Consciousness}

Each of the program's components helps create and define an academic culture that promotes critical consciousness. Capper et al (2006) are strong advocates for the use of curricula "to develop a critical consciousness within future leaders for social justice" (p. 214). That heightened level of consciousness is then manifested through an expanded knowledge of social justice and demonstrated skills in rejecting injustice, inequity, and unethical practices. The aforementioned researchers define critical consciousness "as a deep understanding of power relations and social construction including White privilege, heterosexism, poverty, misogyny, and ethnocentrism" (Capper et al., 2006, p. 213). It is that definition which is adopted and operationalized within the program and, therefore, employed within this article.

\section{Reconciling curriculum and critical consciousness}

As one of only a handful of CPED EdD programs with an emphasis in Higher Education Administration, the program (through its 48 credit hour curriculum ${ }^{3}$ ) focuses exclusively on global awareness of persistent and systemic inequities in higher education, recent developments in higher education, advanced policy analysis, and social justice leadership through efficacious and ethical practice. The curriculum is purposefully designed to expose students to issues of limited access and inequitable practices that impede postsecondary student success. This design goal is accomplished via a critical review of recent developments, contemporary issues, and advanced policies in higher education, coupled with an array of core content courses that improve students' research and analytic proficiency (see Appendix B)

The degree program culminates with a capstone project based on research focused through the lens of professional practice. Inherently applied in nature, the capstone project or dissertation-inpractice (DIP) requires students (either individually or as a collective) to address a meaningful problem of practice in any college or university setting (Carnegie Project on the Education Doctorate, 2016) — large and small, public and private, two- and four-year, research, vocational, teaching, minority serving, and so on. The project is also conducted in consultation with university-community stakeholders that include (among others) higher education practitioners, senior level administrators, policy makers, and researchers. In turn, those stakeholders-who notably have a vested interest in resolving the shared problem of higher education

\footnotetext{
${ }^{3}$ The program requires continuous enrollment of six credit hours for eight consecutive semesters; therefore, it is designed for completion during a three-year period.
}

practice-serve as contributors to and/or members of the DIP committee. ${ }^{4}$

This notion of a shared problem of practice is the ultimate, curricular indication of a programmatic effort to raise consciousness among students about broader perspectives and persistent issues of practice relating to socio-economic and higher educational attainment inequities. In addition to broadening the scope of perspectives that are considered and acknowledged, this social justice preparatory approach helps students (a) understand and fully appreciate the broad (and in some cases conflicting) stakeholder perspectives that exist around a socially pressing issue of practice in higher education and (b) contemplate authentic and socially democratic ways to communicate with and engage those stakeholders in key decision-making processes focused on lasting resolutions. Programmatic emphases are placed on the recognition of broad stakeholder perspectives and the democratic engagement of those stakeholders because it is important to highlight varying dynamics of power and privilege among stakeholder groups. In essence, students need to be and are made aware that some stakeholders traditionally possess and assert more power and privilege because of their cultural, social, political, and/or economic capital. Making certain that students understand the situational context in which that power and privilege manifests is paramount to the program's ability to cultivate students' social justice leadership skills so that they might effectively and consistently resist injustice and ensure the democratic disbursement of power and privilege to all stakeholders at all times, regardless of their traditional standing, thereby creating more equitability.

\section{Reconciling pedagogy and critical consciousness}

Beyond representation within the curriculum, critical consciousness is fully embodied within the program's signature pedagogy of applied learning. ${ }^{5}$ Applied learning is "often equated to hands on or practical learning experiences" (Harrison, 2006, p. 2). The program's faculty selected applied learning because of the embedded opportunities to apply leadership theories and social justice principles to complex problems of higher education practice. Although somewhat of an oversimplification, the main goal of this preferred pedagogy is to provide EdD students with focused problems of practice in higher education, which demonstrate the nuances and perpetuation of inequity in college access, success, and completion, thereby raising student consciousness about persistent inequities and injustices across the higher education

\footnotetext{
${ }^{4}$ The DIP committee is extended to additional university-community stakeholders to help and not hinder doctoral students in their endeavors to address persistent and complex problems of higher education practice. As such, students are allowed the freedom and flexibility needed to take risks and fully explore all conceivable resolutions, even if those resolutions challenge normative behavior in higher education administrative practice.

${ }^{5}$ While it is true that applied learning is the program's signature pedagogy, it is not the only pedagogy used by the faculty. Collaborative learning is also employed by various faculty members; however, applied learning is used the most frequently by all of the program's faculty members in each of the courses.
} 
landscape. To do so, the program utilizes the DIP as the optimal, applied learning tool.

Specifically, the DIP is divided into three applied projects that build on each other in complexity and scope. The projects are tackled during pre-determined points in the doctoral program based on content and research methodological exposure. For instance, the first project entails a detailed review of the literature (i.e., pertaining to the chosen higher education issue). EdD students commence working on this project during the second semester of their first year of doctoral studies, after completing a methods course that teaches them about models of inquiry and literature reviews. Students then enroll in two research methodology courses (qualitative research and advanced statistics) during the fall and spring semesters of their second year. Afterwards, they commence working on the second project-which requires the selection of a methodological concentration to assist with the analysis of their chosen problem of practice. The third project begins after students have completed all but one of the core content courses and after they have written and defended their DIP prospectus.

As a reminder, the DIP is literally termed the dissertation in practice. Applied in nature, the DIP emphasizes unique, complex, and extremely persistent problems of higher education practice that create and/or reinforce disparities in educational and socio-economic attainment. The intended purpose of the DIP is to raise students' consciousness about structural and systemic inequities resulting from ineffective, higher education practices, while also empowering them as administrators and practitioners to remedy those inequities by way of the program's signature pedagogy (i.e., applied learning). Students are made aware when applying that they will be completing an action-oriented and applied capstone project that addresses a persistent problem of higher education practice. Therefore, their orientation to administrative activism and social justice leadership begins the moment they express interest in the CPED EdD program. Important lessons concerning critical consciousness are strategically integrated into the program's informal and formal curriculum even before matriculation.

To complement the DIP, an additional cadre of applied learning tools are employed and interspersed throughout the program of study (see Appendix B). Students are asked to complete a number of assignments and engaged activities that (a) awaken them to inequitable and unjust realities permeating the whole of higher education and (b) encourage them to competently seek out lasting remedies:

1. Revisioning secondary and postsecondary curricula and co-curricula with more equitable opportunities and resources to encourage student success

2. Completing educational and ethno-autobiographies to help identify personal biases, prejudices, and assumptions

3. Responding to reflective, group discussion prompts designed to develop and cultivate critical thinking and analytic skills, while promoting important lessons of objectivity, civility, and respect

4. Analyzing case studies of higher education practices, opportunities, and lessons concerning effective and ineffective social justice leadership

5. Viewing documentaries that address higher educational inequities and injustices

6. Listening to higher education administrative speakers, panels, podcasts, interviews, and TED talks that focus on the challenges and opportunities stemming from integrating equity, social justice, and ethics into one's professional practice

7. Conducting career histories by interviewing seasoned, higher education administrators who actively promote and engage in social justice leadership (and have done so for some time)

8. Engaging in focused, group discussion on current administrative practices and models (i.e., across institutional types) in addition to higher education policies that impede student success

\section{Cultivating Social Justice Knowledge}

If students are to become effective and efficient social justice leaders, they must have a working knowledge of social justice leadership approaches. Capper et al. (2006) firmly uphold that "school leaders for social justice need to know about evidence-based practices that can create an equitable school" (p. 213). Although their commentary is specific to secondary administrators, there is direct and immediate applicability to postsecondary and continuing education administrators. Helping students understand "the positive and equitable effects" of social justice practices is the end goal (Capper et al., 2006, p. 213). From a higher education programmatic perspective, the development of specific, equity-based knowledge to accomplish this goal (i.e., decreased disparities in college access, success, and completion) is no small undertaking. It requires deep concentration on the defined curriculum and prescribed pedagogy.

\section{Reconciling curriculum and social justice knowledge}

An early examination (i.e., reviews of course sequences, syllabi, descriptions, and textbooks) of the program's initial curriculum reveals a concentrated focus on social justice and equity issues relating to higher education practice. ${ }^{6}$ The program works diligently to address-by way of course integration-administrative and practice-based issues of equity. This requires full and unrelenting support from the faculty. It is seemingly understood that no single faculty member is solely responsible for promoting social justice and equity. That responsibility belongs to and is embraced by all program faculty members, regardless of tenure status or eligibility.

Although, each course is purposefully designed to address issues of power and privilege as well as systemic and structural inequities in higher education (see Appendix B), there are two specially designated courses. The first course is offered during the very first semester of the doctoral program and is aptly titled, "Recent Developments in Higher Educational Practice." The embedded content affords doctoral students an opportunity to investigate and evaluate recent policy developments and contemporary innovations designed to mediate inequities in college access, student success, and degree completion. The second course, "Education and Society," is intentionally offered during the second semester of the

\footnotetext{
${ }^{6}$ As a reminder, the program has only admitted two cohorts, to date. The first cohort is now in the second year of coursework and still has one year of designated coursework to complete.
} 
first year, as a follow-up to the previous course. It focuses entirely on issues of equity and difference as well as power and privilege among socio-cultural factors and economic trends affecting the organization, process, and equity outcomes of higher education. Combined, the designated courses and coordinated faculty efforts help orient doctoral students to social justice and equity issues in higher education.

\section{Reconciling pedagogy and social justice knowledge}

The teaching strategies that help students understand and cement their knowledge of the social justice and equity-oriented curriculum are multifold. Within the confines of the CPED EdD program, the individual strategies are left to the discretion of each instructor. It has already been established that applied learning is the program's signature pedagogy, as it is used the most frequently among all of the program's faculty members in each of the courses. There are, however, other pedagogies employed by faculty in some (but not all) of the courses. One such pedagogy is collaborative learning. It is predicated on the notion that knowledge is a social construct. The instructional emphasis is always the student, and interacting and performing a focused act of learning are of the utmost importance (Barkely, Cross, \& Howell Major, 2005; Bruffee, 1998). Additionally, groups are an integral part of learning, and analyzing and solving problems are considered absolutes (Barkely, Cross, \& Howell Major, 2005; Bruffee, 1998). Although collaborative learning is not the signature pedagogy, its general principles are considered meaningful and, therefore, loosely inform the CPED EdD program.

\section{Developing Social Justice Skills}

Capper et al. (2006) argue "there are specific skills that [educational] leaders require to enact justice" (p. 213). Without question, those skills should enable higher education administrators and student personnel professionals "to put their knowledge and [critical] consciousness into practice" (Capper et al., 2006, p. 213). Those sentiments are shared among the current program's instructional faculty. Beyond their newfound knowledge and enhanced awareness, the hope is that students enrolled in the CPED EdD program will walk away with social justice leadership skills, savviness, and expertise. To help ensure these outcomes, program faculty dutifully attend to the curriculum and pedagogy.

\section{Reconciling curriculum and social justice skills}

The program upholds the curriculum as a content-specific domain that teaches students how to implement what they have learned, so as to eradicate inequities and injustices in higher education. Admittedly, this is no easy task. To assist, the instructional faculty has adopted a very succinct set of analytic guides that clearly outline what students should be able to do (i.e., to address systemic and structural, inequities in higher education) upon completion of the program. The instructional faculty members recognize that more often than not, students initially identify symptoms of social justice and equity-based problems before realizing the underlying problems. To remedy this, they developed the first guide-which assists with problem identification and entails the review of recent and contemporary events and relevant happenings along a historic timeline. This historical review enables students to trace the symptoms to an originating source or to the root of the social justice and equity-based problem of practice. The second guide helps students further contextualize the problem and necessitates the consideration of divergent stakeholder views and perspectives. This includes vulnerable and marginalized stakeholders. The third guide calls for responsive decision-making using an analytic and holistic lens through which students are able to more clearly envision appropriate and lasting solutions.

At first glance, these analytic guides may seem overly broad and non-specific to social justice leadership. It is suggested, however, that the guides empower students so they might effectively contextualize the meaning of important policy events and institutional or unit happenings as they relate to an identified problem of higher education practice. In addition, the guides prompt students to recognize diverse stakeholder perspectives at all times, so as to engage in equitable, socially just, and ethical decision-making. Finally, the guides encourage students to engage in holistic and informed decision-making when addressing inequities and injustices in higher education. The hope is that by adhering to the guides, students will essentially be able to create socially just and inclusive environments for all higher education stakeholders. Further, they will be able to implement comprehensive and long-lasting reform efforts/programs that root out inequities in college access, student success, and college completion. This potentially means strategically addressing issues regarding the lack of diversity and inclusivity among students, faculty, and staff, but it could also mean aggressively tackling persistently polarizing and contentious topics that adversely affect campus climate. Seeking out and listening to marginalized, unfavored, and/or forgotten voices could also fall well within students' realm of administrative responsibility. Importantly, these are healthy and expected outcomes, proficiencies, and/or skills, all of which are linked to the program's use and promotion of the analytic guides for realizing effective, social justice leadership.

\section{Reconciling pedagogy and social justice skills}

The CPED EdD program employs a number of strategies to help students learn how to be socially just administrators. As mentioned, a great deal of discretion is left to the instructional faculty regarding the employed strategy. However, in evaluating the program, there are numerous strategies that stand out. The use of administrative equity and social justice management simulations is one such strategy. Faculty members also encourage group discussion of disparate stakeholder views and brainstorming around consensus building strategies. In addition, students are asked to develop a social justice administrative/philosophy statement along with a social justice leadership concept map and/or conceptual rendering that includes evidenced-based practices. As a complement to these activities, faculty assist students in drafting a formal letter of application to a fictional higher education position vacancy listing that requires an operational description of one's commitment to social justice leadership. Opportunities to visit local, regional, national, and international higher education policy entities and institutions that regularly promote social justice initiatives are also made available. Although non-exhaustive, these preferred strategies paint a composite portrait of the variety of thoughtful activities, methods, and approaches that are utilized within the program to help students learn the skills needed to become social justice leaders.

\section{DISCUSSION \& IMPLICATIONS}

The current analysis is very unique to CPED and higher education practice because it entails an implementation evaluation of a graduate program in Higher Education Administration. Unlike their 
secondary counterparts, Higher Education Administration programs in general have no accrediting body and, therefore, are not subjected to external evaluations. There are national associations that are specific to higher education administrative practice and research (e.g., the Association for the Study of Higher Education, American Educational Research Association / Division J, NASPA / Student Affairs Administrators in Higher Education, the American College Personnel Association, etc.). However, there is no professional accreditation required for Higher Education Administration programs, nationally or internationally, and the Higher Education Administration program described in this paper is no exception to this extraordinary non-rule. ${ }^{7}$

Even so, the assessed program differs from its higher education counterparts because of its participation in CPED. As mentioned, CPED is a consortium of over 80 schools of education that seek to reform and innovate the educational doctorate (i.e., both secondary and postsecondary). The selected program was created in an attempt to reenvision the Higher Education Administration doctorate for practitioner scholars to be more applied and useful in everyday, institutional settings. In reenvisioning the doctorate, the research methodological requirements were not relaxed. Instead, they were retooled to complement the administrative preparatory purpose of social justice leadership (see Appendix B). The latter actually became the sole focus of the selected program's CPED doctorate. The faculty aspired to prepare and develop more critically conscious, knowledgeable, and competent social justice leaders in higher education. To place equity, social justice, and ethics at the center of their core operation was a bold statement, as the stakes were and still are very high. However, even in its early implementation stages, the evaluated program has successfully managed to transform the Higher Education Administration doctorate in a legitimate, highquality, and scholarly manner. In essence, in their attempts to prepare more socially just leaders, the faculty compromised nothing. The rigor and quality that one would expect in more traditional, Higher Education Administration programs is ever present and so too are the expectations for doctoral student excellence in empirical inquiry and analysis. The value that has been added to this newly formatted, doctorate inherently stems from its (a) applied pedagogy and capstone dissertation, (b) expanded definition of institutional stakeholders, and (c) recognition of mutuality in identifying persistent problems of practice.

The acknowledgement of an expanded university-community and the need to democratically engage ${ }^{8}$ all community stakeholders (including those who are considered non-traditional ${ }^{9}$ ) in complex decision-making and resolutive processes is made apparent not only

${ }^{7}$ It is important to acknowledge this fact because of the embedded opportunities within the current discussion to model to other higher education programs ways to implement social justice leadership preparatory programs and promote specific learning outcomes, like competencies in social justice leadership.

${ }^{8}$ Democratic engagement implies that the perspectives of all stakeholders are not only acknowledged and respected but hold equal and valued weight.

${ }^{9}$ In this case, non-traditional voices include individuals and entities that are traditionally excluded from academia because they lack the requisite credentials and higher education experience. during the completion of the DIP but rather throughout the program, with the inclusion of special university-community panels and guest speakers-all of whom focus on pressing, social justice issues related to access and equity in higher education. Using Capper et al.'s (2006) social justice framework for preparing leaders provides a detailed assessment and extremely robust evaluation of the program's implementation thus far. Because of the domain-specific structure of the framework, the richness of the evaluation truly lies within the explanatory details. No programmatic stone was left unturned, and the resulting analysis revealed a complex and comprehensive programmatic operation that promoted (a) critical consciousness about higher education inequities, (b) theory and evidence-based knowledge about persistent problems in higher education practice, and (c) focused knowledge of how to address the inequities and practice-based problems. Each of these components is critical to the programmatic development of social justice leaders in higher education.

The implications of these components and others highlighted within the article are far reaching, as they will help shape and (in some cases) redefine $\mathrm{PhD}$ as well as $\mathrm{EdD}$ programs in Higher Education Administration. Essentially, these components-once made known to the more expansive Higher Education community outside of the CPED consortium — can serve as the beginning of a movement across all Higher Education Administrative preparatory programs (i.e., at the master's and doctoral level) to pay specialized and continuous attention to the preparation of more socially just leaders and practitioners. What is described here is a ripple effect with seemingly broad ramifications relating to higher education practice and research.

\section{CONCLUSION \& OPPORTUNITIES FOR FURTHER ANALYSIS}

Social justice leadership is not an elusive, administrative ideal. It is, in fact, a tangible reality that has existed for quite some time (i.e., since the inception of higher education). Whether through research or practice, there have always been advocates and advocacy movements for social justice in higher education. The most noted and discussed periods of advocacy in academe occurred during the Women's Suffrage Movement, the Progressive Era, and the Civil Rights Movement. In fact, the Industrial Revolution along with the emancipation of the American slaves, the passing of the Morril Acts and the GI Bill, the Higher Education Act, affirmative action, and more recent shifts toward holistic admissions have all helped usher in progressive policies that promote social justice and equity in higher education.

So, why is the deliberate preparation of social justice leaders in higher education such a programmatic novelty? This is, of course, a rhetorical question, but it sheds light on one of the most pressing (yet understated) higher education issues of the $21^{\text {st }}$ century. In this age, higher education is quickly shifting to a mass education modelwhich results in changing student demographics. As student demographics change, so too do student learning and developmental needs. Issues of access, accountability, affordability, and attrition are then pushed to the forefront (Altbach, Gumport, \& Berdahl, 2011), and colleges and universities must respond in an effective manner while balancing their ever-dwindling budgets.

If this sounds like a conundrum, it is because it really is an administrative quagmire. Yet, what is perhaps more troubling is the fact that there is no coordinated initiative in higher education 
regarding the strategic preparation and professional development of social justice leaders for $21^{\text {st }}$ century colleges and universities (i.e., external to CPED). How can this problem be overlooked for so long? Where is the clarion call for reform within Higher Education Administration doctoral programs? Why isn't anyone making the critical linkages between Higher Education Administrative preparatory practices and student success? From an institutionalization perspective, it is not a far reach. In fact, it is a necessary reach for colleges and universities who are serious about addressing systemic and structural inequities concerning access and student success.

This article has attempted to answer the previous questions by focusing the analytic and evaluative lens on a Higher Education Administration program that is seeking to break the mold. Innovative, exacting, and daring in its efforts, the current CPED EdD program is attempting to offer solutions rather than staid platitude, such as "This is the way it has always been done." Perhaps that is the problem. Doctoral programs cannot innovate without change, and the same is true for higher education as a whole. The time has come to modify administrative behaviors, and the only way to do so is by modifying Higher Education Administrative preparatory programs and curricula. Only then will there be a noticeable difference in higher education's ability to effectively respond to new age challenges and opportunities brought forth in this new century.

In closing, there is a great need for more critical analyses and evaluations of existing, Higher Education Administration programs. In general, most programs could benefit from innovation and deliberate retooling. This article describes one such program and its attempts to redesign its core curriculum and pedagogy. More are needed. Simply put, there can be no change without focused and concentrated chaos.

\section{REFERENCES}

Altbach, P. G., Gumport, P. J., \& Berdahl, R. O. (2011). American higher education in the twenty-first century: Social, political, and economic challenges ( $3^{\text {rd }}$ ed.). Baltimore: Johns Hopkins University Press.

American Association of Colleges \& Universities. (n.d.). Making excellence inclusive.Retrieved from https://www.aacu.org/making-excellenceinclusive

Asumah, S. N., \& Nagel, M. (Eds.). (2014). Diversity, social justice, and inclusive excellence: Transdisciplinary and global perspectives. Albany, NY: SUNY Press.

Asumah, S. N., Nagel, M., \& Rosengarten, L. (2016). Two new trends in diversity leadership and inclusive excellence [Special issue]. Wagadu: $A$ Journal of Transnational Women's and Gender Studies, 15 (Summer 2016), 139-161.

Barkely, E. F., Cross, K. P. \& Howell Major, C. (2005). Collaborative learning techniques: A handbook for college faculty. San Francisco: JosseyBass.

Baxter, P., \& Jack, S. (2008). Qualitative case study methodology: Study design and implementation for novice researchers. The Qualitative Report, 13(4), 544-559.

Bensimon, E. M. (2007). The underestimated significance of practitioner knowledge in the scholarship of student success. The Review of Higher Education, 30(4), 441-469.

Berg, G. (2010). Low-income students and the perpetuation of inequality: Higher education in America. Farnham, GB: Routledge. Retrieved from http://www.ebrary.com.umiss.idm.oclc.org

Brown, K. M. (2004). Leadership for social justice and equity: Weaving a transformative framework and pedagogy. Educational Administration Quarterly, 40(1), 77-108. doi: 10.1177/0013161X03259147

Brown, K. M. (2006). Leadership for social justice and equity: Evaluating a transformative framework and andragogy. Educational Administration Quarterly, 42(5), 700-745. doi: 10.1177/0013161X06290650
Bok, D. (2006). Our underachieving colleges: A candid look at how much students learn and why they should be learning more. Princeton: Princeton University Press.

Bowen, W. G., Chingos, M. M., \& McPherson, M. S. (2009). Crossing the finish line: Completing college at America's public universities. Princeton: Princeton University Press.

Bowen, W. G., \& McPherson, M. S. (2016). Lesson plan: An agenda for change in American higher education. Princeton: Princeton University Press.

Braxton, J. M., Doyle, W. R., Hartley, H. V., Hirschy, A. S., Jones, W. A., \& McLendon, M. K. (2014). Rethinking college student retention. San Francisco: Jossey-Bass.

Bruffee, K. A. (1998). Collaborative learning: Higher education, interdependence, and the authority of knowledge ( $2^{\text {nd }}$ ed. $)$. Baltimore: Johns Hopkins University Press.

Capper, C. A., Theoharis, G., \& Sebastian, J. (2006). Toward a framework for preparing leaders for social justice. Journal of Educational Administration, 44(3), 209- 224.

Carlton, E. L., Whiting, J. B., Bradford, K., Hyjer Dyk, P., \& Vail, A. (2009). Defining factors of successful university-community collaborations: An exploration of one healthy marriage project. Family Relations: Interdisciplinary Journal of Applied Family Studies, 58(1), 28-40. doi: 10.1111/j.1741-3729.2008.00532.x

Carnegie Project on the Education Doctorate. (2016). About us [consortium description]. Retrieved from http://cpedinitiative.siteym.com/page/AboutUs

Caruso, R., Bowen, G., \& Adams-Dunford, J. (2006). Student affairs and service learning: Promoting student engagement. The College Student Affairs Journal, 25(2), 186-198.

Center for Urban Education, University of Southern California. (n.d.). Equity Mindedness. Retrieved from https://cue.usc.edu/equity/equitymindedness/

Complete College America. (2013). The five game changers: Are states implementing the best reforms to get more college graduates? Retrieved from http://completecollege.org/resources/

Cress, C. M., Burack, C., Giles, D. E., Elkins, J., \& Stevens, M. C. (2010). A promising connection: Increasing college access and success through civic engagement. Boston: Campus Compact.

Dantley, M. E., \& Tillman, L. C. (2006). Social justice and moral transformative leadership. In C. Marshall \& M. Oliva (Eds.), Leadership for social justice: Making revolutions in education (pp.16-30). Boston, MA: Allyn and Bacon.

Dickert-Conlin, S., \& Rubenstein, R. H. (2007). Economic inequality and higher education: Access, persistence, and success. New York: Russell Sage Foundation.

Dowd, A. D., \& Bensimon, E. M. (2015). Engaging the "race question": Accountability and equity in U.S. higher education. New York: Teachers College Press

Ewell, P. T. (2009). Assessment, accountability, and improvement: Revisiting the tension (Occasional Paper No. 1). Retrieved from National Institute for Learning Outcomes Assessment website: http://www.learningoutcomesassessment.org/documents/PeterEwell007. pdf

Guerra, P. L., Nelson, S. W., Jacobs, J., \& Yamamura, E. (2013). Developing educational leaders for social justice: Programmatic Elements that work or need improvement. Education Research and Perspectives: An International Journal, 40(1), 124-149. Retrieved from http://www.erpjournal.net/wp-content/uploads/2013/04/ ERPV40_Final_Guerra-et-al.-_2013_-Developing-EducationalLeaders.pdf

Guerra, P. L., \& Pazey, B. L. (2016). Transforming educational leadership preparation: Starting with ourselves. The Qualitative Report, 21(10), 1751-1784. Retrieved from http://nsuworks.nova.edu/tqr/vol21/iss10/2

Harrison, L. (2006). What is applied learning?: Exploring understandings of applied learning amongst beginning teachers. In AARE 2006 : Conference papers, abstracts and symposia (pp. 1-14). Paper presented at the meeting of the Australian Association for Research in Education. Coldstream, Vic.

Hillman, N. W., Tandberg, D. A., \& Gross, J. P. K. (2014). Performance funding in higher education: Do financial incentives impact college completions? The Journal of Higher Education, 85(6), 826-857. doi: 10.1353/jhe.2014.0031 
Kotter, J. P. (1990). A force change: How leadership differs from management. New York: The Free Press.

McKenzie, K. B., Christman, D. E., Hernandez, F., Fierro, E., Capper, C. A., Dantley, M., Gonzalez, M. L., Cambron-McCabe, N., \& Scheurich, J. J. (2008). From the field: A proposal for educating leaders for social justice. Educational Administration Quarterly, 44(1), 111-138. doi: 10.1177/0013161X07309470

Mor Barak, M. E. (2014). Managing diversity: Toward a globally inclusive workplace ( $3^{\text {rd }}$ ed.). Thousand Oaks, CA: Sage Publications, Inc.

Nelson, K., Creagh, T., \& Clarke, J. (2012). Social justice and equity issues in the higher education context, literature analysis and synthesis: Development of a set of social justice principles [Monograph]. Retrieved from http://safeguardingstudentlearning.net/wpcontent/uploads/2012/ 05/OLT_MSLE_Project-Literature-Analysis_June12draft3.pdf

Northouse, P. G. (2013). Leadership: Theory and practice (6th ed.). Thousand Oaks, CA: Sage Publications, Inc.

Olsen, J. E., \& Martins, L. L. (2012). Understanding organizational diversity management programs: A theoretical framework and directions for future research. Journal of Organizational Behavior, 33(8), 1168-1187. doi:10.1002/job.1792

Patton, M. Q. (2015). Qualitative research and evaluation methods (4th ed.). Thousand Oaks, CA: Sage Publications, Inc.

Rabovsky, T. M. (2012). Accountability in higher education: Exploring impacts on state budgets and institutional spending patterns. The Journal of Public Administration Research and Theory, 22(4), 675-700.

Rost, J. C. (1991). Leadership for the twenty-first century. Westport, CT: Praeger Publishers.

Seidman, A. (Ed.). (2012). College student retention: Formula for student success $\left(2^{\text {nd }}\right.$ ed.). Lanham, MD: The Rowman \& Littlefield Publishing Group, Inc.

Simonet, D. (2008). Service-learning and academic success: The links to retention research. St. Paul, MN: Minnesota Campus Compact.

Tandberg, D. A., \& Hillman, N. W. (2014). State higher education performance funding: Data, outcomes, and policy implications. Journal of Education Finance, 39(3), 222-243.

Tandberg, D. A., Hillman, N., \& Barakat, M. (2014). State higher education performance funding for community colleges: Diverse effects and policy implications. Teachers College Record, 116(12), 1-31.

Taylor, L. L., Beck, M. I., Lahey, J. N., \& Froyd, J. E. (2017). Reducing inequality in higher education: The link between faculty empowerment and climate and retention. Innovative Higher Education, 1-15. doi: $10.1007 / \mathrm{s} 10755-017-9391-1$

The University of Mississippi. (2014). Curriculum: Doctor of Education with an emphasis in higher education [curriculum description]. Retrieved from http://education.olemiss.edu/_download/Higher_Ed_EdD_Curriculum.pdf

Theoharis, G. (2007). Social justice educational leaders and resistance: Toward a theory of social justice leadership. Educational Administration Quarterly, 43(2), 221-258. doi: 10.1177/0013161X06293717

Thompson, L. S. (2003). Use of a university-community model to frame issues and set an agenda for strengthening a community. Health Promotion Practice, 4(4), 385-392. doi: 10.1177/1524839903255467

Tinto, V. (1993). Leaving college: Rethinking the causes and cures of student attrition ( $2^{\text {nd }}$ ed.). Chicago: University of Chicago Press.

Tinto, V. (2012). Completing college: Rethinking institutional action. Chicago: University of Chicago Press.

Volkwein, J. F., \& Tandberg, D. A. (2008). Measuring up: Examining the connections among state structural characteristics, regulatory practices, and performance. Research in Higher Education, 49(2), 180-197.

Williams, D. A., Berger, J. B., \& McClendon, S. A. (2005). Toward a model of inclusive excellence and change in postsecondary institutions. Washington, DC: Association of American Colleges and Universities.

Yin, R. K. (2003). Case study research: Design and methods ( $3^{\text {rd }}$ ed.). Thousand Oaks, CA: Sage Publications. 


\section{APPENDIX A}

Table A: A Framework for Preparing Social Justice, Education Leaders

\begin{tabular}{|l|l|l|l|}
\hline Emotional Safety for Risk Taking & Critical Consciousness & Knowledge & Skills \\
\hline Curriculum & & & \\
\hline Pedagogy & & & \\
\hline Assessment & & & \\
\hline
\end{tabular}

Note. The first domain in the horizontal dimension (i.e., Emotional Safety for Risky Taking) is continuously upheld by the program faculty at the course and program level as well as when working with the university-community stakeholders on a shared problem of practice in higher education. Adapted from "Toward a Framework for Preparing Leaders for Social Justice,” by C. Capper, G. Theoharis, and J. Sebastian, 2006, Journal of Educational Administration, 44(3), p. 212. Copyright 2006 by the Emerald Group Publishing Limited.

\section{APPENDIX B}

Table B: EdD Program of Study

\begin{tabular}{|c|c|c|c|}
\hline & YEAR ONE & YEAR TWO & YEAR THREE \\
\hline FALL & $\begin{array}{l}\text { Recent Developments in Higher } \\
\text { Educational Practice } \\
\text { Models of Inquiry \& Literature Review }\end{array}$ & $\begin{array}{l}\text { Multi-Disciplinary Perspectives on } \\
\text { Leadership } \\
\text { Qualitative Research }\end{array}$ & $\begin{array}{l}\text { Dissertation in Practice } \\
\text { (6 credit hours; Projects } 2 \& 3 \text { ) }\end{array}$ \\
\hline SUMMER & $\begin{array}{l}\text { Seminar on the Learner \& Learning } \\
\text { The Professional Philosophy }\end{array}$ & $\begin{array}{l}\text { Institutional Research \& Planning in Higher } \\
\text { Education } \\
\text { Dissertation in Practice (Project 2) } \\
{ }^{*} \text { Comprehensive Exam }\end{array}$ & \\
\hline
\end{tabular}

Note. Students are responsible for fulfilling all course prerequisites if not fulfilled during their Master's degree program. The program of study includes 15 semester hours to work on the Dissertation in Practice-which is comprised of a scaffolded, capstone project. Adapted from "Curriculum: Doctor of Education with an Emphasis in Higher Education," by The University of Mississippi, School of Education. Copyright 2014 by The University of Mississippi. 